International Journal Management Science \& Business

Vol 1, No 1, 2019, pp 1-14

\title{
Accountability and Transparency : Application of Good Educational Governance
}

\author{
Darmawan \\ Program Studi Manajemen Keuangan Syari'ah, Fakultas Ekonomi dan Bisnis Islam, \\ Universitas Islam Negeri Sunan Kalijaga, Yogyakarta, Indonesia
}

\begin{abstract}
Aims of research is to determine the quality of financial management at the madrasah tsanawiyah in the region of the office Ministry of Religious Affairs Bandung district. The issue is how much influence the accountability and transparency to madrasah financial management at public madrasah Tsanawiyah in Bandung district. The method used is survey method explanative with quantitative data analysis, data collection techniques conducted through questionnaires and document review and interviews. The results showed about madrasah financial management in the Ministry of Religious Affairs Office of Bandung district, as follows: 1. the magnitude of the relationship simultaneous between $X 1$ and $X 2$ to $Y$ is high which 0.768 . While the contribution together variables $X 1$ and $X 2$ to $Y$ by 59\%. The results of descriptive analysis of the variable $Y$, the most powerful indicator of the organization and coordination of $83.36 \%$ while the lowest indicator is $77.99 \%$ for controls; 2 . The relationship variable $X 1$ on $Y$ is 0.762 while the contribution of variables $X 1$ to $Y$ by $58.1 \%$. The testing of hypothesis saw that significantly affects the accountability to financial management. The results of descriptive analysis of the variables X1, the most powerful indicator is periodic and annual financial statements of $82.31 \%$ while the weakest indicator is the quality of the preparation of APBM of $66.85 \%$; 3 . The relationship variables $X 2$ to $Y$ is 0.636 while the contribution of variables $X 2$ to $Y$ by $40.4 \%$. The testing of hypothesis saw that significantly influences the transparency to financial management. The results of descriptive analysis on the variables $X 2$, the most powerful indicator is the assurance of integrity by $81 \%$ while the weakest indicator is the availability of information to the public at 68.81\%; 4. In general it can be concluded that the accountability and transparency of financial management in the Ministry of Religious Affairs Office of Bandung district has been running well but there needs to be increased to achieve the expected results.
\end{abstract}

Keywords : Accountability; transparency; madrasah financial management.

Corresponding author. E-mail address: darmawan@uin-suka.ac.id

Received December 2018; Received in revised February 2019; Accepted May 2019

International Journal Management \& Busines Vol 1, No 1 (2019) 1-14

\section{Introduction}

The paradigm of reform in Indonesia is mark by the emergence of the spirit of democratization, accountability, and transparency in every aspect of life. Phenomena occurring in the public sector development in Indonesia today are a stronger demand for accountability for public institutions, both at central and regional levels. According to Indra
Bastian (2007: 52), in the service and the provision of education, limited allocation of funds from the government is one of the obstacles that make the quality of school education has not budged. To that end, schools must use the funds effectively and efficiently as possible in order to improve service and quality of school education. If government funding is 
inadequate, the school may seek through funds from the public. Management of funds, from government and from society, should be based on the spirit of accountability and transparency. With the transparent management of funds, the public can find out where the funds were spent on schools.

During this time, the school only has the reports and letters as a form of accountability transparency of financial management school. Now the statement of cash flows, as well as the calculation of the cost spent by each school is expected to have an accountability report, including financial statements consisting of the school budget, reports surplus deficit and students. So that the government and the public can more easily find out how much each student needs in each month, semester, or year. The next government can take actions and policies related to education sector development. In other words, the school's financial reporting should be able to provide useful information for the providers of funds and other users, both current and potential, in making rational decisions about the allocation of funds to the school.

Now every school has a School Committee as a watchdog. However, in many schools, the school committee does not have adequate access to these funds. The school committee was more often the legitimator for every step of the principal. The position of treasurer of the committee are usually held by one of the teachers at the school that in fact subordinate to the principal, so the principal doings in the use of school funds almost uncontrolled (Bastian, 2007 :91).

Based on the above understanding, motivations underlying this research are first, there has been no research on transparency and accountability in financial management of madrasahs in Bandung district. Second, the facts of the alleged distortions in the allocation of the budget at the school, lack of supervision of financial management in the madrassas the country, on the other side accountable to the Committee on Madrasah always be well received, and still have not explained the mechanism of regulation of the financial reporting entity in the education unit. In Bandung district, this is especially true in the management of BOS, both in the provincial and district levels. Also on the management of funds in the form of GAKIN management grants to poor students many of whom are not distributed according to their function.

For that, we need scientific research to find empirical proof about the relationship of transparency and accountability for financial management education units, researchers focused on a Public MTs in Bandung district.

\section{Literature Review}

Scientific research is a form of research in ways of thinking and acting systematically. Therefore, studies need to be supported by a foundation or basis of the theory of reference in analyzing the issues and provide clarity of direction in conducting further research; it will be elaborated on a theoretical framework that deals with aspects - aspects of this writing.

\section{Financial Management}

Although not the only source of performance, finance madrassas is certainly an undeniable part as an important staple in the development of madrasah. Finance and funding is one of the resources that directly support the effectiveness and efficiency of education management. This is again more pronounced in the implementation of the MBS (School-Based Management), which requires the ability 
madrasah for planning, implementing and evaluating and managing the funds in a transparent accountable to the people and government.

Finance and financing in providing education is crucial and an integral part in the research of education management. Financial components and financing at a madrasah is a component of production that determines the implementation of teaching and learning activities at the school along with other components. In other words, any activityundertaken madrasah cost, be it conscious or unconscious. Financial components and financing are need to be managed as well as possible, so that there are funds that can be used optimally to support the achievement of educational goals.

Without a clear vision of an administrator of a reliable, (Mohammad Rais, 2008: 249) madrasah development that rely solely idealism, will hit the wall of reality that is not necessary. In preparing the Strategic Plan and further to RAPBM education course required of a competent administrator.

Objectives of Financial Management Education in the perspective of public administration is to assist the management of financial resources and educational organizations to create appropriate control mechanisms, for financial decision-making in the educational attainment of organizational goals transparent, accountable and effective. Good control of the administration of the financial management of education will provide a good social responsibility to the various interested parties (stakeholders).

According to the PP. 482008 on Education Funding Article 58, Principles in the management of education funds by the Government, local governments, providers and educational unit established by the community consists of a. general principle, and b. specific principles. The general principle referred to in Article 58 letter is a. principles of justice; $b$. principle of efficiency; c. principles of transparency, and $d$. principle of public accountability.

Hereinafter Transparency and public accountability became the main indicator in nearly every assessment of the quality of financial management of a madrasah. While these regulations have not been explained in more detail these two principles, so it needs to provide further explanation about the philosophy to the instrument builders of these two principles.

Conceptual definition of financial management throughout the madrassas are the efforts of financial management component and the madrassas that are managed as well as possible financing, so that goals can be achieved madrasah effectively and efficiently, within which covers the cost of investment, operating costs, and personal expenses.

\section{Accountability}

Asian Development Bank confirms a consensus that good governance based on four pillars: (1) accountability, (2) transparency, (3) can be predicted and (4) participation (ADB, 1999). It is clear that the number of components or underlying principles of good governance vary greatly from one institution to another institution, from one expert to another expert. At least there are a number of principles, which are considered as the main principles that underlie good governance, namely (1) Accountability, (2) Transparency, and (3) Public Participation.

However, accountability is the key principle of all these (ADB, 1999) this principle 
requires two things: (1) the ability to answer (answerability), and (2) the consequences (Consequences). The first component (a term that originated from responsibility) is associated with demands for the authorities to periodically answer any questions relating to how they use their authority, where resources have been used, and what has been achieved using these resources.

There are eight things to be done by schools to increase accountability: First, schools should develop rules about the system of accountability, including accountability mechanisms. Second, schools need to develop guidelines for behavior and school system performance monitoring and supervision system operator with clear and firm sanctions. Third, schools and school development plans to deliver a public / stakeholders at the beginning of each fiscal year. Fourth, develop a clear indicator of school performance measurement and communicated to stakeholders. Fifth, take measurements of performance achievement of educational services and deliver the results to the public / stakeholders at the end of the year. Sixth, to respond public questions and complaints. Seventh, provide information to the public school activities that will get educational services. Eighth, to renew the performance of the new plan as a new commitment agreement. On the eighth attempt, everything rests on the ability and willingness of schools to make it happen. Instead of the school to know its resources, so it can be mobilized to create and enhance accountability. Schools can involve stakeholders to develop and update the system considered cannot guarantee the realization of accountability in schools. School committees, parents, professional groups, and government can be involved to implement it. With so stakeholders from the beginning will know and feel they have an existing system.

Conceptual definition of accountability in this research is a measure that indicates the extent of compliance with the provision of services on the size of the values and norms held by external stakeholders with an interest in such services.

\section{Transparency}

Transparency is a principle, which guarantees freedom of access or for any person to obtain information about the governance, information on the policymaking process and implementation, and results achieved (BAPENAS, 2002: 18)

Transparency of the policy is open to scrutiny. While the definition of information is information about every aspect of government policy that are accessible to the public. Disclosure of information is expected to produce a healthy political competition, tolerant, and policies are made based on public preferences (Meuthia Gani, 2000: 151). This principle has two aspects, namely (1) public communications by the government, and (2) the right of people to access information. Both will be very difficult if the government does not deal well performance. A good performance management is the starting point of transparency.

During this time, especially before the era of decentralization and reform, the management of education in many schools is much closed to outsiders. Community, parents and most teachers do not know much about the management of school education, do not know income and expenditure the school, and they are not involved in evaluating the strengths and weaknesses of school performance. 
Lack of transparent management give negative impact on the development of schools as communities and parents will wonder if when they were asked to participate in thinking about education funding shortfall, the contribution they provide will really be used for educational or irregularities that would not be expected? On the other hand, school leaders are applying a closed management feels that the other party does not need to interfere with school management issues because it was simply handled by the principal and staff of the two principal beliefs. They worry that disclosure would be very inconvenient and cannot solve the problems facing the school.

Transparency in the management consists of 1 ) the financial management, transparency in income and school expenditures from government, donors and other sources. 2) Management of staff / personnel: workforce requirements, qualifications, abilities and weaknesses, the need for professional development, etc. 3) Management of the curriculum, including openness in terms of student achievement and performance, the availability of facilities and infrastructure supporting the implementation of the curriculum, vision, mission, and education quality improvement program.

Conceptual definition of transparency in this research is the principle which guarantees freedom of access or for any madrasah stakeholders to obtain information about the financial management of the madrasahs, which is information about the policy making process and implementation, as well as the achieved results the madrasah.

\section{Definition and Characteristics of Madrasah}

Even though technically, in the teachinglearning process, madrasah are not formally different from the school, but in Indonesia madrasah are not understood as a school, but given a more specific connotation, namely "religious school", where students get kids learning of things or the intricacies of religion and religious (in this case Islam).

In practice there are madrassas that besides teaching religious sciences (al-'ulum aldiniyyah), also taught the sciences that are taught in public schools. In addition there are madrassas that only specialize in the subject of religious sciences, the so-called madrassa diniyyah. The fact that the word "madrasah" is derived from Arabic and not translated into Indonesian, causing more people to understand the "madrasah" as an Islamic educational institutions, namely the "place to study religion" or "place to provide religious instruction and religious".

\section{Objective}

Based on the issues that have been the writer suggested above, the purposes of this research are:

a. Analyze the effect of accountability on financial management of madrasahs in the Ministry of Religious Affairs Office of Bandung district.

b. Analyze the effect of transparency on the financial management of madrasahs in the Ministry of Religious Affairs Office of Bandung district.

c. Analyze the effect of accountability and transparency simultaneously on financial management of madrasahs in the Ministry of Religious Affairs Office of Bandung district.

\section{Research Methods}

Population and Sample

The number of members of the Committee is 9 members, Teacher / Employee 
numbered 120 people so that the overall population of 129 people. Sample in this research is set equal to the population, because of the overall population is relatively small (approximately 100 people). So the sampling technique used in this research were saturated sampling techniques in accordance with this opinion Sugiyono (2007:96) says that "saturation sampling technique is the technique of determining if all members of the population sample used as a sample. The other term is a census sampling saturation ". Based on the above opinion sampling is conducted on every member of the population that is internal stakeholders within the Ministry of Religious Affairs Office of Bandung district with number 129.

\section{Types and techniques of data collection}

Data types used are the primary data, taken directly from the source / respondents through a questionnaire and secondary data, taken from the document analysis and literature research.

\section{Methods and Data Analysis Techniques Descriptive Analysis}

Descriptive analysis is a statistical function to provide an overview of the object under research through the sample data as it is. Descriptive analysis is used to determine the respondent's answer to the ideal score by using the following formula:

$$
P=\frac{\sum S R}{\sum S I} \times 100 \%
$$

Data values can be specified categories of the general condition of a variable, whether it is worth variable high, medium, and low.
Description of the answer will refer to the interpretation of the following categories:

$20-35,99 \%$ categorized as not good; $36-$ $51,99 \%$ categorized as good enough; 52 $69,99 \%$ categorized as medium; $68-83,99 \%$ categorized as good; $84-100 \%$ categorized as very good; This interpretation is adapted from the score category Likert.

\section{Path Analysis}

The magnitude of the direct effect of an exogenous variable on endogenous variables, expressed by the value of numerical coefficient of the path (path coefficient) from exogenous to endogenous.

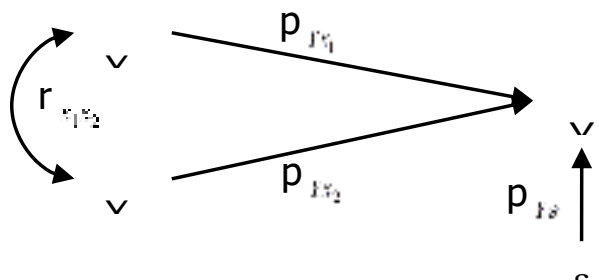

Figure 1

\section{Causal relationship of $X_{1}, X_{2}$ to $Y$}

The relationship between $X_{1}$ and $X_{2}$ is a correlational relationship. The intensity of the closeness of the relationship is expressed by the magnitude of the correlation coefficient $\mathrm{r}^{x_{1} x_{2}}$. The magnitude of the direct effect of $X_{1}$ to $Y$, and from $X_{2}$ to $Y$, each of which is expressed by the magnitude of the numerical value of the coefficient of the path $\mathrm{p}^{Y x_{1}}$ and $\mathrm{p}^{Y x_{2}}$. Path coefficients $\left(\mathrm{p}^{Y \varepsilon}\right)$ describing the magnitude of the direct influence of the residual variable to $Y$. (implicit exogenous variable). Numerical values of path coefficients can be concluded that the percentage of how much the variable residue, how to calculate $100 \%-\left(\mathrm{p}^{Y x_{1}}+\mathrm{p}^{Y x_{2}}\right)=\mathrm{p}^{Y \varepsilon}$ so that we can find out what percentage of 
variables that have not been included in the model of causal relations $X_{1}, X_{2}$ to $Y$.

Formula to calculate the correlation coefficient is Product Moment Coefficient of Karl Pearson. The reason the use of techniques of Karl Pearson correlation coefficient is due to the variables that want to look for correlations have interval measurement scale. The formula is:

$$
r_{x y}=\frac{N \sum X Y-\left(\sum X\right) \cdot\left(\sum Y\right)}{\sqrt{\left[N \sum X^{2}-\left(\sum X\right)^{2}\right]\left[N \sum Y^{2}-\left(\sum Y\right)^{2}\right]}}
$$

Identify the sub-structure and the equation coefficients to be calculated on track, which is expressed by the equation:

$\mathrm{Y}=\mathrm{p}^{y x_{1}} \mathrm{x}_{1}+\mathrm{p}^{y x_{2}} \mathrm{X}_{2}+\ldots+\mathrm{p}^{y x_{k}} \mathrm{x}_{\mathrm{k}}+\varepsilon$

Received by the influence of an endogenous variable from two or more exogenous variables, can be individually or jointly. The magnitude of the direct influence of exogenous variables on endogenous variables $=$ $\mathrm{p}^{y x_{i}} \times \mathrm{p}^{y x_{i}}$. The magnitude of the indirect effect of variables exogenous to endogenous variables $=\mathrm{p}^{y x_{i}} \mathrm{X} \mathrm{r}^{x_{1} x_{2}} \times \mathrm{p}^{y x_{i}}$. The magnitude of the influence of exogenous variables on total endogenous variable is the sum of the amount of direct influence by the amount of indirect

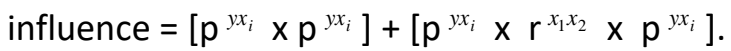

Significance test of each path coefficient has been calculated, either individually or jointly, as well as examine the differences in the degree of influence of each exogenous variable on endogenous variables.

1. Statistical hypothesis (operational hypotheses) to be tested.
○ $\mathbf{H}_{\mathrm{o}}: \mathrm{p}^{y x_{i}}=0$ meaning there is no influence of exogenous variables $\left(X_{i}\right)$ of the endogenous variable $(\mathrm{Y})$.

○ $\mathbf{H}_{1}: \mathrm{p}^{y x_{i}} \neq 0$, meaning there is the influence of exogenous variables $\left(X_{i}\right)$ of the endogenous variable $(\mathrm{Y})$.

Where $u$ and $i=1,2, k$

2. Statistical tests:

- To test each path coefficients:

$$
t=\frac{p_{y x_{i}}}{\sqrt{\frac{\left(1-R^{2} y\left(x_{1} x_{2} \ldots x_{k}\right)\right.}{n-k-1} C_{i i}}}
$$

Testing criteria: Disapproved $\mathrm{H}_{0}$ if the calculated value $t$ greater than $t$ table value. $\left(t_{0}>t_{\text {able }}(n-k-1)\right)$.

- To test the overall path coefficients:

$$
F=\frac{(n-k-1)\left(R_{y\left(x_{1}, x_{2}, \ldots x_{k}\right)}^{2}\right)}{k\left(1-R_{y\left(x_{1}, x_{2}, \ldots x_{k}\right)}^{2}\right)}
$$

Testing criteria: Disapproved $\mathrm{H}_{0}$ if the calculated $F$ value is greater than the table value $F$. $\left(F_{0}>T_{\text {able }(k, n-k-1)}\right)$.

- To examine differences in the degree of influence of each exogenous variable on endogenous variables.

$$
t=\frac{p_{y x_{i}}-p_{y x_{j}}}{\sqrt{\frac{\left(1-R_{y\left(x_{1} x_{2} \ldots x_{k}\right)}^{2}\right)\left(C_{i i}+C_{j j}-2 C_{i j}\right)}{n-k-1}}}
$$

Testing criteria:

$\mathrm{H}_{0}$ is rejected if the value of $\mathrm{t}$ bigger than value $t$ tables. $\left(t_{0}>t_{a b l e}(n-k-1)\right)$. 
In the above formulas the meaning of each symbol is $\mathrm{I}=1,2, \mathrm{k}, \mathrm{k}=$ number of exogenous variables in the substructure under test, $\mathrm{t}=$ follow $\mathrm{F}$ distribution table, with degrees of freedom $k$ and $n-k-1$.

\section{Results and Discussion \\ Characteristics of Respondents}

The research was conducted on 129 people madrasah internal stakeholders, the madrasah committee, teachers, and administrators at the public madrasah tsanawiyah in the Ministry of Religious Affairs Office of Bandung district. One hundred and nineteen questionnaires distributed to respondents by courier, the number of return is 64 so that the percentage rate of return of $53.78 \%$.

Based on research results known to the data characteristics of the respondents were as follows: that the madrasah committee who were respondents in the research as many as 3 people or $4.69 \%$, teachers 54 people or $84.38 \%$, and the administration of 7 people or $10.94 \%$. The number of men who were respondents in this research of 25 people or $39.06 \%$ whiles the number of women 54 people or $84.38 \%$. Madrasah Tsanawiyah education personnel in the Ministry of Religious Affairs Office of Bandung district have met the qualification standards of teachers.

\section{Validity testing}

The validity test performed on all items in the statement of the research instrument by connecting score points with the total score on each construct. Then compared with the value of the coefficient of the critical value of $r$ (Nisfiannoor M, 2009). If the coefficient value is greater than the number of critical values, then the item is declared valid. $\mathrm{R}$ of the table for the 64 respondents with a significance level of $5 \%$ obtained for $0.246 \mathrm{r}$ table. From the results of data processing was found 56 items that are otherwise not valid. The items have the highest validity is item 39 is a 0.814 correlation value of the indicator formulation, budget execution and reporting publicly madrasah in the variable transparency. While the grain that has a validity of 50 items with the lowest correlation value 0.263 of the planning process in a variable indicator of financial management.

\section{Reliability testing}

Reliability testing of the reliability testing results shows the reliability of question items used in this research. Research questions in the questionnaire items are considered reliable if cronbach coefficient alpha value $>0.60$ (Nunnaly in Ghozali, 2001: 133). Reliability test results are presented in detail in the following table:

\section{Table 1. Reliability test results}

\begin{tabular}{cccc}
\hline No & Variables & $\begin{array}{c}\text { Cronbach } \\
\text { Alpha }\end{array}$ & Conclusion \\
\hline 1 & Accountabilit & 0.933 & Reliable \\
2 & Transparenc & 0.944 & Reliable \\
3 & Managemen & 0.876 & Reliable \\
\hline \multicolumn{2}{l}{ Sources: } & Primary Data Processing &
\end{tabular}

This suggests that the reliability of test results from all of the variables in this research expressed reliable.

\section{Descriptive analysis}

To give an idea of the influence of accountability and transparency of the financial management of the madrasahs, in the Ministry of Religious Affairs Office of Bandung district. Therefore, in this section, the researchers will 
International Journal Management Science \& Business

Vol 1, No 1, 2019, pp 1-14

describe these variables based on the responses of respondents in the questionnaire research.

\section{Accountability Variable Analysis}

Frequency distribution of the responses to the four indicators of accountability $\left(\mathrm{X}_{1}\right)$ can be seen in the explanation of the frequency distribution data scores as follows:

a. Indicator of the quality of budgeting (APBM). The result of 64 responses to the 11 items respondents question the actual total score can be determined from the responses of 2353 and achieved the highest possible score is $5 \times 11 \times 64=3520$. Calculate the percentage of degrees than the actual score is the ideal score (2353: 3520$) \times 100 \%=$ $66.85 \%$. Seen the percentage of scores obtained from responses to the criteria of 64 respondents were medium. This means that the quality of the preparation of APBM not so good, not in accordance with the rules and failed to accommodate the interests of stakeholders madrasahs as a whole.

b. Indicators of the Periodic and Annual Financial Report. The results of the 64 responses to the 5 question responders can know the actual total score of the responses of 1317 and achieved the highest possible score is $5 \times 5 \times 64=1600$. Calculate the percentage of degrees than the actual score is the ideal score $(1317: 1600) \times 100 \%=$ $82.31 \%$. Seen the percentage of scores obtained from responses to the 64 respondents were either criterion. This means that the periodic and annual financial statements have been going well, delivered on time and in accordance with predetermined rules.

C. Indicators of Participation of Stakeholders in Creating Accountability. The results of 64 respondents response to question 6 points can be determined from the actual total score of the responses of 1503 and achieved the highest possible score is $5 \times 6 \times 64=1920$. Calculate the percentage of degrees than the actual score is the ideal score (1503: 1920) $x$ $100 \%=78.28 \%$. Seen the percentage of scores obtained from responses to the 64 respondents were either criterion. This means that the participation of stakeholders in creating accountability has gone well.

d. Overall Accountability indicator. The results of 64 respondents response to question can be determined from the actual total score of 492 respondents and achieved the highest possible score is $5 \times 2 \times 64=640$. Calculate the degree of actual percentage score compared to the ideal score is (492: 640) $x$ $100 \%=76.88 \%$. Seen the percentage of scores obtained from responses to the 64 respondents were either criterion. This means that the overall accountability has gone well.

Overall, the criteria of financial accountability at the public madrasahs in the Ministry of Religious Affairs Office of Bandung district.

$\frac{2353+1317+1503+492}{3520+1600+1920+640} \cdot 100 \%=73.76 \%$.

Although it could be categorized as good, of course, the financial accountability of these public madrasah should be further enhanced, because the percentage is not too large.

\section{Transparency variable analysis}

a. Indicators of Clarity Management Roles and Responsibilities of School Finance. The results of 64 respondents response to question can be determined from the actual total score of 736 respondents and achieved 
the highest possible score is $5 \times 3 \times 64=960$. Calculate the degree of actual percentage score compared to the ideal score is (736: $960) \times 100 \%=76.67 \%$. Seen the percentage of scores obtained from responses to the 64 respondents were either criterion. This means that the clarity of roles and responsibilities of financial managers of the school has gone well.

b. Indicator of the availability of information for the Public. The results of the 64 responses to the 5 question responders can know the actual total score of the responses of 1101 and achieved the highest possible score is $5 \times 5 \times 64=1600$. Calculate the percentage of degrees than the actual score is the ideal score $(1101: 1600) \times 100 \%=$ $68.81 \%$. Seen the percentage of scores obtained from responses to the 64 respondents were either criterion. This means that the availability of information to the public has been given quite well by the financial manager.

c. Formulation, Implementation, and Reporting Openly School Budget. The results of 64 respondents response to question 9 items can be determined from the actual total score of the responses of 2264 and achieved the highest possible score is $5 \times 9 \mathrm{x}$ $64=2880$. Calculate the percentage of degrees than the actual score is the ideal score (2264: 2880$) \times 100 \%=78.61 \%$. Seen the percentage of scores obtained from responses to the 64 respondents were either criterion. This means that the preparation, execution, and reporting publicly the school budget has been going well.

d. Indicators of Integrity Assurance. The results of the 64 responses to the 5 question responders can know the actual total score of the responses of 1296 and achieved the highest possible score is $5 \times 5 \times 64=1600$. Calculate the percentage of degrees than the actual score is the ideal score (1296: 1600) $x$ $100 \%=81.00 \%$. Seen the percentage of scores obtained from responses to the 64 respondents were either criterion. This means that the guarantees have been provided with good integrity.

Overall, the criteria for financial transparency in the public madrasah in the Ministry of Religious Affairs Office of Bandung district conditions can be determined by performing the calculation: the sum of the actual total score divided by the total number of ideal score multiplied by 100 .

$\frac{736+1101+2264+1296}{960+1600+2880+1600} \cdot 100 \%=76.66 \%$.

Although the condition of transparency of madrasah finances in the Ministry of Religious Affairs Office of Bandung district can be said to be good, but still needs to be improved because the percentage is still small, especially in accordance with Section 31 of the availability of madrasah financial management information media.

\section{Analysis of Variable Management}

a. Indicators of Process Planning. The results of the 64 responses to the 5 question responders can know the actual total score of the responses of 1586 and achieved the highest possible score is $5 \times 6 \times 64=1920$. Calculate the percentage of degrees than the actual score is the ideal score (1586: 1920) $x$ $100 \%=82.60 \%$. Seen the percentage of scores obtained from responses to the 64 respondents were either criterion. This 
International Journal Management Science \& Business

Vol 1, No 1, 2019, pp 1-14

means that the plan has been implemented properly.

b. Indicators of Organization and Coordination. The results of 64 respondents responses to 8 items can be known to question the actual total score of the responses of 2134 and achieved the highest possible score is $5 \times 6 \mathrm{x}$ $64=2560$. Calculate the percentage of degrees than the actual score is the ideal score (2134: 2560$) \times 100 \%=83.36 \%$. Seen the percentage of scores obtained from responses to the 64 respondents were either criterion. This means that the organization and coordination has been implemented properly.

c. Indicators of implementation and reporting. The results of 64 respondents responses to 3 item may be known to question the actual total score of the responses of 770 and achieved the highest possible score is $5 \times 3 \mathrm{x}$ $64=960$. Calculate the degree of actual percentage score compared to the ideal score is $(770: 960) \times 100 \%=80.21 \%$. Seen the percentage of scores obtained from responses to the 64 respondents were either criterion. This means that implementation and reporting of financial management of madrasah has been implemented properly.

d. Supervision. The results of 64 respondents response to question 7 points can be determined from the actual total score of the responses of 1747 and achieved the highest possible score is $5 \times 3 \times 64=2240$. Calculate the percentage of degrees than the actual score is the ideal score (1747: 2240) $x$ $100 \%=77.99 \%$. Seen the percentage of scores obtained from responses to the 64 respondents were either criterion. This means that the surveillance had been implemented properly.
Overall, the criteria for the condition of financial management at the public madrasah in the region of the Ministry of Religious affair Bandung district can be determined by performing the calculation: the sum of the actual total score divided by the total number of ideal score multiplied by 100 .

$$
\frac{1586+2134+770+1747}{1920+2560+960+2240} \cdot 100 \%=81.21 \% \text {. }
$$

Good criterion is of course still to be done to improve, especially in monitoring indicators remained below $80 \%$.

\section{Hypothesis testing - Correlation analysis}

Relationship between accountability $\left(X_{1}\right)$ and Financial Management $(\mathrm{Y})$ at $r=0.762$ and obtain $\mathrm{p}=0.000<0.01$, so $\mathrm{H}_{0}$ : rejected and $\mathrm{H}_{1}$ : accepted. Means There are positive and significant correlation between accountability to the management. Accountability increasingly positive, the higher management. Conversely, the more negative the lower the Management Accountability. Relationship between transparency $\left(\mathrm{X}_{2}\right)$ and Financial Management $(\mathrm{Y})$ at $r=0.636$ and obtain $p=0.000<0.01$, so $\mathrm{H}_{0}$ : rejected and $\mathrm{H}_{1}$ : accepted. Means There are positive and significant correlation between the transparencies of the management. The more positive transparency, the higher management. Conversely, the more negative the lower the transparency of the management.

1. Path analysis

\section{a. Correlations}

Based on the calculations, the correlation between variables obtained figures Accountability and Transparency of 0.751. Correlation of 0.751 has a mean correlation between variables Accountability and transparencies are very strong and unidirectional (because it is positive). 
Accountability means that if the height direction of the transparency is high. The correlation of two variables are highly significant because the number of significance of $0.000<0.01$.

\section{b. Regression}

In this section, the analysis is divided into two. The first is to look at the combined effect and the second is the influence of the partial view.

\section{Accountability and Transparency effects} simultaneously on Financial Management.

To find Accountability and Transparency effects simultaneously on Financial Management, we will see the results of calculations in the model summary, especially the number $\mathrm{R}$ square: square magnitude of the numbers $R\left(r^{2}\right)$ is 0.590 . The number is used to see the huge influence of variable Accountability and Transparency of Financial Management by calculating the coefficient (KD) by using the following formula:

$K D=r^{2} \times 100 \%$

$K D=0,590 \times 100 \%=59 \%$

This figure has meant that the Accountability and Transparency effects simultaneously on Financial Management basis were $59 \%$, while the remaining $41 \%$ (100\% $59 \%)$ influenced the other factor. In other words, the variability of Financial Management, which can be explained by using the Accountability and Transparency variable, is equal to $59 \%$, while outside of this model is $41 \%$.
Figures obtained from the calculation ( $\mathrm{F}$ studies) 43.924> 3.15 (table F). Thus, $\mathrm{H}_{0}$ rejected and $H_{1}$ accepted. This means that there is a linear effect between variables Accountability and Transparency in Financial Management. Above regression model is already feasible and true. In conclusion, Accountability and Transparency variables simultaneously affecting financial management. The influence is $59 \%$. The influence of variables other than the regression model was calculated by the formula:

$1-r^{2}$ or $1-0.590=0.410$ or $41 \%$.

\section{The partial effect of variable Accountability and Transparency to Financial Management}

Based on calculations derived figures ( $t$ research) 5.261> 1.999 (table $t$ ), then $\mathrm{HO}$ refused and $\mathrm{H} 1$ accepted. That is, there is a linear effect between accountability and financial management. The magnitude of the influence of accountability on the financial management is 0.653 or $65.3 \%$. Based on calculations derived figures (not research) 1169 $<1.999$ (table $\mathrm{t}$ ), then $\mathrm{HO}$ refused and $\mathrm{H} 1$ accepted. That is, there is no significant linear effect between transparency and financial management. The magnitude of the influence of transparency on the financial management is 0.145 or $14.5 \%$.

\section{Path Diagram}

Based on all the calculations and analysis has been done in the previous section, the path diagram obtained as follows: 


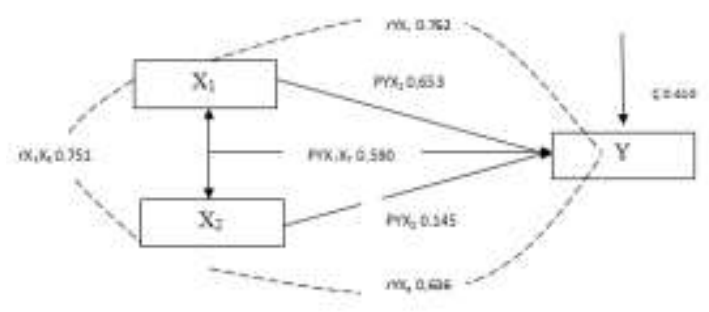

Figure 2. Path Diagram

So that the structural equation to get the path diagram above as follows:

$Y=0.653 X_{1}+0.145 X_{2}+\zeta ̧$

Thus, the effect of the Financial Management Accountability partially is 0.653 or 65.3\%. Effect of Transparency of Financial Management partially is 0.145 or $14.5 \%$. Effect of Accountability and Transparency of financial management simultaneously is 0.59 or by $59 \%$. In addition, other influences that are not covered by these two variables were $41 \%$. The correlation between Accountability and Transparency is 0.751 . The correlation between the accountability to the Financial Management is 0.762 and a correlation between the transparencies to the financial management is 0.636 .

\section{Conclusions}

Based on this research, some can be inferred. First, the results of hypothesis testing has concluded that the correlation of the Accountability of Financial Management. There is positive and significant relationship between accountability to the management. Accountability increasingly positive than then increased the management. Conversely, more negative the accountability lowers than decreased the Management.

Second, the results of hypothesis testing has concluded that the correlation of the Transparency of Financial Management. Means
There is a positive and significant relationship between the transparencies to the management. The more positive transparency, than increased the management. Conversely, more negative transparency the lowers than decreased the management.

Third, accountability and transparency simultaneously affect the financial management of $59 \%$. There is a significant influence of Accountability to Management. On the other hand, data obtained from these respondents showed no significant effect of the transparency of management. Although it generally indicates that, there is significant influence of the Accountability and Transparency to Management. With effect of $59 \%$, we can say that accountability provides a greater contribution. Alternatively, we can say that accountability is more influential than the transparency of management. This can be seen also from the magnitude of the value of beta.

Fourth, most of the indicators that contributed to the significant influence of the accountability variable are an indicator variable Quality Management Financial Budgeting and the next row indicator Periodic Financial Reports, Participation and Accountability Stakeholders Overall. While the indicators are built Transparency variable scale effect is not strong enough to make the variables significantly affect the variable transparency of financial management.

\section{Recommendation}

The low degree of influence of transparency on financial management in this research would provide a separate concern. Because this will eventually result in Quality finance management at the madrasah in the Ministry of Religious Affairs will decline. The low perception of respondents towards 
transparency will allow decreasing the level of awareness of stakeholders on financial management at the madrasah. Therefore, one day without supervision and in-depth involvement of all stakeholders, of course, financial management at the madrasah will decrease. Therefore, it was necessary in anticipation by the authorities in advance of external stakeholders. Because the relative external stakeholders are free of conflicts of interest in the madrasah environment.

\section{References}

Amien Rais, Mohammad, 2008. Selamatkan Indonesia! Agenda - Mendesak Bangsa, PPSK press.

Asian Development Bank, 1999. Governance : Sound Development Management.

Bapennas, 2002. Buku Pedoman Penguatan Pengamanan Program Pembangunan Daerah, Badan Perencanaan Nasional \& Departemen Dalam Negeri.

Bastian, Indra, 2007. Akuntansi Pendidikan, Penerbit Erlangga, Jakarta.

Ghozali, Imam. 2002. Statistika.

Mardiasmo, 2006. artikel “Pewujudan Transparansi dan Akuntabilitas Publik Melalui Akuntansi Sektor Publik: Suatu Sarana Good Governance" dalam JURNAL AKUNTANSI PEMERINTAH, Vol. 2, No. 1, Mei 2006.

Mardiasmo, Akuntansi Sektor Publik, Penerbit Andi, Yogyakarta.

Meuthia, 2000. artikel "Good Governance : Prinsip, Komponen dan Penerapannya", dalam HAM : Penyelenggaraan Negara Yang Baik dan Masyarakat Warga, Jakarta : KOMNAS HAM.
Nisfiannor, Muhammad, 2009. Pendekatan Statistika Moderen untuk IImu Sosial. Salemba Humanika.

Sugiyono. 2003. Statistika untuk Penelitian, Cetakan Kelima, CV Alpha Betha, Bandung. 